\title{
A brief review of the bilayer electrolyte strategy to achieve high performance solid oxide fuel cells
}

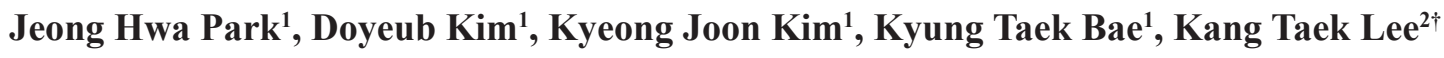 \\ ${ }^{1}$ Department of Energy Science and Engineering, Daegu Gyeongbuk Institute of Science and Technology (DGIST), \\ Daegu, 42988, Republic of Korea \\ ${ }^{2}$ Department of Mechanical Engineering, Korea Advanced Institute of Science and Technology (KAIST), \\ Daejeon, 34141, Republic of Korea
}

\section{고성능 고체산화물 연료전지를 위한 이중층 전해질 전략}

\author{
박정화 ${ }^{1}$, 김도엽 ${ }^{1}$, 김경준 ${ }^{1}$, 배경택 $^{1}$, 이강택 ${ }^{\dagger}$ \\ ${ }^{1}$ 대구경북과학기술원 에너지공학전공, ${ }^{2}$ 한국과학기술원 기계공학과
}

(Received May 5, 2020; Accepted June 2, 2020)

\begin{abstract}
The solid oxide fuel cells (SOFCs) are the one of the most promising energy conversion devices which can directly convert chemical energy into electric power with high efficiency and low emission. The lowering operating temperature below $800{ }^{\circ} \mathrm{C}$ has been considered as the mostly considerable research and development for commercialization. The major issue is to maintain reasonably high performance of SOFCs at reduced temperatures due to increment of polarization resistance of electrodes and electrolyte. Thus, the alternative materials with high catalytic activities and fast oxygen ion conductivity are required. For recent advances in electrolyte materials and technology, newly designed, highly conductive electrolyte materials and structural engineering of them provide a new path for further reduction in ohmic polarization resistance from electrolytes. Here, a powerful strategy of the bilayer concept with various oxide electrolytes of SOFCs are briefly reviewed. These recent developments also highlight the need for electrolytes with greater conductivity to achieve a high performance, thus providing a useful guidance for the rational design of cell structures for SOFCs. Moreover, cell design, materials compatibility, processing methods, are discussed, along with their role in determining cell performance. Results from state-of-the-art SOFCs are presented, and future prospects are discussed.
\end{abstract}

Keywords: solid oxide fuel cells, high performance, electrolytes, bilayers

${ }^{\dagger}$ Corresponding Author: Kang Taek Lee

E-mail: leekt@kaist.ac.kr 


\section{1. 서론}

현재의 주 에너지원은 석유나 석탄 등의 화석연료에 의존 하고 있고, 화석연료 연소에 따른 환경오염문제와 채취량의 한계에 따른 화석연료의 고갈 문제가 발생하 고 있다. 이로 인해 지구 온난화와 같은 환경적인 이슈 와 에너지 부족 문제가 크게 대두되고 있으며, 이러한 문제를 해결하기 위해서 수력, 화력, 원자력 등과 같은 기존의 발전방식보다 효율적이고 환경 친화적인 새로운 에너지 시스템의 개발이 활발히 진행되고 있다. 그중에 서도 연료 전지는 수소 또는 화석연료의 화학에너지를 전기화학반응을 통해 직접 전기를 얻을 수 있는 장치로, 연료의 연소반응 없이 1 차 에너지 변환 과정만으로 전 기를 얻을 수 있기 때문에 에너지 변환 효율이 높다. 따 라서, 열기관에 비교했을 때 연료 소비가 적고 오염물질 및 온실가스 배출량을 크게 감소시킬 수 있다. ${ }^{1-4)}$

고체산화물 연료전지(SOFC)는 전기 변환 효율이 가 장 높을 뿐만 아니라 높은 구동 온도 $\left(\geq 800{ }^{\circ} \mathrm{C}\right)$ 로 인 한 일련의 전기 화학 반응을 통해 연료 유연성을 가지므 로 다양한 유형의 메탄, 프로판, 메탄올 및 바이오매스 와 같은 탄화수소, 그리고 수소와 같은 중요한 에너지원 으로의 변환이 가능하다. 또한, 구성요소가 고체산화물 형태로 이루어져 있기 때문에 다른 연료전지에 비해 구 조가 간단하고, 파손 및 부식의 문제를 최소화 시킬 수 있다. 따라서, $\mathrm{SOFC}$ 는 고성능 및 고내구성을 동시에 기 대할 수 있는 차세대 연료전지 기술로 각광받고 있다. ${ }^{5}$ $\mathrm{SOFC}$ 는 기본적으로 치밀한 전해질 (electrolyte), 그리
고 다공성 구조의 공기극 (cathode) 및 연료극 (anode) 로 구성된다. 공기극에서, 산소 분자는 외부 회로로부터 전자를 통해 산소이온 형태로 바뀌며 (식(1)), 이는 전해 질을 통하여 연료극 쪽으로 이동한다. 연료극에서 산소 이온은 수소 분자와 만나 물을 형성하면서 (식(2)), 전자 를 외부 회로로 방출한다(식(3)) (Fig. 1).

이때, 전해질은 다양한 범위의 산소 분압 $\left(\mathrm{pO}_{2}: 1-10^{-}\right.$ $22 \mathrm{~atm})$ 에 걸쳐 화학적/구조적으로 안정해야하며, 높은 이온 전도 특성을 가져야 한다. ${ }^{6}$ 또한, 전자를 차단함으 로써 두 전극이 직접 접촉하는 것을 방지할 수 있으며, 하나의 전극에서 다른 전극으로 하전 된 이온의 흐름이 전체 전하 균형을 유지할 수 있다.

$\mathrm{SOFC}$ 의 높은 구동 온도는, 장기 구동 시 각 구성 요 소 간 화학적/구조적 열화 현상이 발생하기 쉽고, 단전 지를 연결하는 소재의 선택성의 한계가 있다. 열적 내구 성이 강한 고가의 소재들을 사용해야 하기 때문에, 경쟁 기술 대비 낮은 경제성이 단점이다. 이러한 문제점을 해 결하기 위해, 작동 온도를 낮추는 중저온형 $\left(<800{ }^{\circ} \mathrm{C}\right)$ 고체산화물 연료전지를 개발하는 연구가 활발히 진행되 고 있다. ${ }^{7-9)}$ 작동 온도를 낮추게 되면, 스택 및 소재 간 연결 접합재의 비용을 낮출 수 있으며, 저가의 금속 및 세라믹의 폭 넓은 선택이 가능해진다. 또한, 각 구성 산 화물의 재료 선택이 다양해져 시스템 비용이 더욱 절감 될 수 있으며, 강도 및 화학적/구조적 안정성 측면에서 내구성이 향상 될 수 있다. 하지만, 구동 온도가 낮아지 게 되면, 열 활성 반응이 감소하게 되어 전극의 산소환 원반응 (oxygen reduction reaction, ORR) 및 수소산

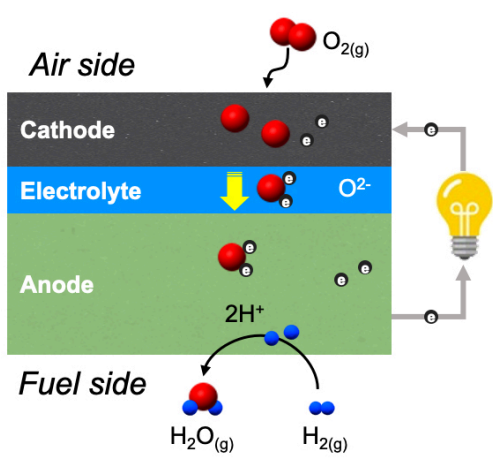

Fig. 1. Schematic diagram of solid oxide fuel cells.
공기극 (cathode) : $\frac{1}{2} \mathrm{O}_{2}+2 e^{-} \leftrightarrow \mathrm{O}^{2-}$

연료극 (anode) : $\mathrm{H}_{2}+\mathrm{O}^{2-} \leftrightarrow \mathrm{H}_{2} \mathrm{O}+2 e^{-}$(2)

전체 반응 (Overall) : $\mathrm{H}_{2}+\frac{1}{2} \mathrm{O}_{2} \leftrightarrow \mathrm{H}_{2} \mathrm{O}$ 
화반응 (hydrogen oxidation reaction, HOR), 그리고 전해질의 이온전도 저항이 크게 증가하게 된다. 따라서, 낮아진 구동 온도에서 높은 속도의 이온 전도 및 반응을 활성화시키기 위한, 다양한 종류의 전해질 및 전극을 개 발하는 방법 등이 연구되고 있다. ${ }^{1,5}$

본 기고문에서는 중저온형 고성능 고체산화물 연료전 지를 위한, 다양한 전해질 최근 연구동향과, 차세대 이 중층 전해질 기술 및 전망에 대하여 소개하고자 한다.

\section{2. 본론}

\section{1 고체전해질의 특징과 종류}

전해질은 $\mathrm{SOFC}$ 의 핵심 구성요소로서, 공기극과 전 해질 계면에서 환원 된 산소이온을 산소 빈자리 호핑 메 커니즘을 통해 연료극으로 전달시키는 역할을 한다. 지 난 몇 십년간, 다양한 산소이온 전도 산화물의 특성과 $\mathrm{SOFC}$ 전해질 재료로 광범위한 연구가 진행되어 왔다. $\mathrm{SOFC}$ 용 전해질의 특징으로, 효율적으로 작동하기 위한 주요 요구사항은 다음과 같다. ${ }^{6}$

(i) 높은 산소이온 전도도 $(>0.1 \mathrm{~S} / \mathrm{cm})$ : 전해질의 핵심 요소 중 가장 중요한 것으로, $\mathrm{SOFC}$ 셀의 오믹 손실 (Ohmic loss)이 결정되므로, 높은 이온전도성을 가 진 소재를 전해질로 선택해야 한다. 전해질의 두께가 $10 \mu \mathrm{m}$ 인 $\mathrm{SOFC}$ 단전지에서 $1 \mathrm{~W} / \mathrm{cm}^{2}$ 이상의 최대 출력 밀도 (Maximum power density, MPD)를 지 니기 위해서는 $0.1 \mathrm{~S} / \mathrm{cm}$ 보다 높은 이온전도성을 가 져야 하고, $0.15 \Omega-\mathrm{cm}^{2}$ 보다 작은 면저항을 가져야 한다고 알려져 있다. 이온전도도는 다음과 같은 식으 로 정의될 수 있다.

$$
R_{\text {ohmic }}=\frac{L_{E}}{\sigma A}
$$

$\mathrm{R}_{\text {Ohmic }}$ 은 오믹 저항, $\sigma$ 는 전해질 이온전도도, $\mathrm{L}_{\mathrm{E}}$ 는 전 해질 두께, 그리고 $\mathrm{A}$ 는 면적을 나타낸다.

(ii) 다양한 산소 분압 $\left(p_{\mathrm{O}_{2}}: 1-10^{-22} \mathrm{~atm}\right)$ 에서의 구조적/ 화학적 안정성: 전해질을 중심으로 공기극과 음극으 로 분리가 되기 때문에, 상대적으로 넓은 범위의 산 소 분압에 노출된다. 따라서, 산화 및 환원 분위기에
서 높은 안정성이 요구된다.

(iii) 낮은 전자 나름수 (electron transference number) $\left(<10^{-4}\right)$ : 낮은 전자 나름수는 전자전도성 이 제한되어 전해질 내부로의 누설 전류 (leakage current)가 거의 나타나지 않는 순수한 이온 전도 특성을 나타낸다. 따라서, 산소이온만 전도 되고 전 자에 대해서는 절연체이어야 한다.

(iv) 충분한 기계강도 (> $400 \mathrm{Mpa}$ ): SOFC 단전지 제조 및 장기 구동 시, 가해지는 압력과 온도 변화에 대 한 충격에 내구성이 강한 소재를 선택해야 한다.

(v) 구성 물질 간의 화학적 안정성 및 적절한 열팽창 계 수 (thermal expansion coefficient, TEC): 다양한 온도에서 소재들의 화학적 안정성을 보이기 위해, 적절한 열팽창 계수가 요구된다. 잦은 열 사이클 구 동과 장기 구동에 따른 구성 요소 간 계면의 높은 내 구력을 가진 재료여야 한다.

현재 대부분의 상용화된 SOFC 전해질 소재로는 이 트리아 안정화 지르코니아 (yttria stabilized zirconia, $\mathrm{YSZ}$ ) 소재를 사용한다. $\mathrm{YSZ}$ 는 고온 (> $800{ }^{\circ} \mathrm{C}$ ) 에서 높은 이온 전도성과 우수한 화학적/구조적 안정성을 가 지고 있으며, 또한 전자 전도성이 거의 없어 전압 효율 손실과 산소 누출과 같은 문제점을 최소화 시키는 장점 이 있다. 하지만, 고효율/고안정성 $\mathrm{SOFC}$ 를 개발하기 위해서는 낮은 구동 온도에서 더 높은 이온 전도도를 가 지는 전해질 재료를 선택해야하며, 이를 개발하기 위한 연구가 매우 활발하게 이루어지고 있다. 일반적으로, 이 온전도는 격자내의 결함을 통하여 산소이온이 이동하는 현상으로 격자 이온의 크기가 서로 다른 도펀트를 치환 하는 기술을 통해, 결함을 제어하는 연구가 진행되고 있 다. 따라서, 넓은 범위의 다양한 도펀트를 수용할 수 있 으며, 첨가물의 설계가 용이한 형석 (fluorite) 과 페로 브스카이트 (perovskite) 구조의 산화물 이온전도체의 개발이 가장 많이 이루어지고 있다. 형석 구조로는 지르 코니아 및 세리아, 그리고 비스무스계열의 산화물이며, 페로브스카이트 구조로는 란타넘-갈레이트계열 등이 있으며, 격자 내 산소 결핍에 따라 산소이온이 전달된다 (Fig. 2). ${ }^{10)}$ 


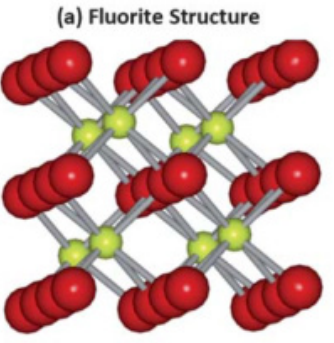

(b) Oxygen transport path in the fluorite structure

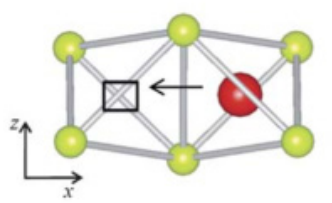

Fig. 2. Crystal lattice and oxygen migration path in the fluorite $(a, b)$ and perovskite structure for SOFC electrolytes. ${ }^{10)}$

이온전도도는 아레니우스 식을 통해 다음과 같이 정 의 될 수 있으며(식(4)), 형석과 페로브스카이트 구조 기 반의 다양한 산화물계 전해질의 대표적 이온전도도를 온도에 따라 나타내었다(Fig. 3).

$$
\sigma T=A \exp \left(-\frac{E_{\mathrm{a}}}{\kappa T}\right)
$$

\subsection{1. 지르코니아계열}

현재 가장 많이 사용되고 있는 고체산화물 연료전 지용 전해질 소재는 지르코늄 산화물 $\left(\mathrm{ZrO}_{2}\right)$ 이다. 순 수한 $\mathrm{ZrO}_{2}$ 는 대표적인 절연체 소재로, 동질이상

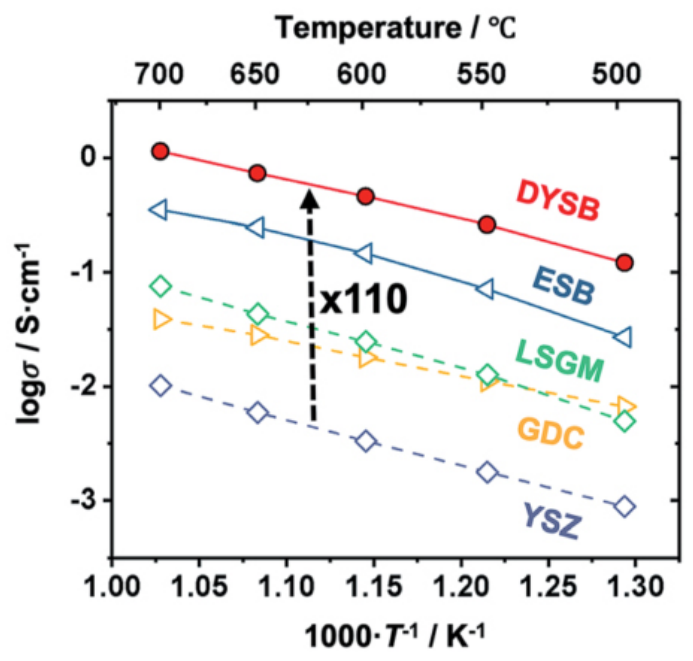

Fig. 3. Conductivity of solid electrolytes for SOFCs. ${ }^{9}$ (polymorphism)의 특성을 지닌다. 상온에서는 단사정 계 (monoclinic) 구조이며, $1170{ }^{\circ} \mathrm{C}$ 이상에서는 정방정 계 (tetragonal), $2370{ }^{\circ} \mathrm{C}$ 이상에서는 등축정계 형석 (cubic fluorite) 구조를 지닌다. 하지만 순수한 $\mathrm{ZrO}_{2}$ 는 $1170{ }^{\circ} \mathrm{C}$ 에서 정방정계에서 단사정계로 상전이 되는 과 정에서 3-5\%의 큰 부피변화를 동반하기 때문에 알칼리 희토류 또는 희토류산화물을 첨가하여 상온에서도 상을 안정화 시킬 수 있다. ${ }^{6,11)} \mathrm{CaO}, \mathrm{MgO}$ 와 같은 알칼리희 토류를 사용하여 $\mathrm{ZrO}_{2}$ 를 안정화 할 경우 기계적 특성을 향상시킬 수 있으며, $\mathrm{Y}_{2} \mathrm{O}_{3}, \mathrm{Yb}_{2} \mathrm{O}_{3}, \mathrm{Gd}_{2} \mathrm{O}_{3}, \mathrm{Sc}_{2} \mathrm{O}_{3}$ 과 같 은 희토류산화물을 사용할 경우 전기적 특성을 향상 시 킬 수 있다. ${ }^{12,13)}$ 가장 대표적인 지르코니아계 고체산화 물 소재는 $8 \mathrm{~mol} \%$ 의 $\mathrm{Y}_{2} \mathrm{O}_{3}$ 을 도핑하여 상을 안정화 시 킨 YSZ 이다. $\mathrm{YSZ}$ 의 이온전도도는 $1000{ }^{\circ} \mathrm{C}$ 에서 $0.1 \mathrm{~S} /$ $\mathrm{cm}$ 로, 고체산화물 연료전지용 전해질로 $1 \mathrm{~W} / \mathrm{cm}^{2}$ 의 최 대 출력 밀도를 지니기 위해 요구되는 최소 이온전도도 를 만족한다. 지르코니아를 안정화시키기 위한 다양한 도펀트 소재 중에서, $\mathrm{Sc}_{2} \mathrm{O}_{3}$ 를 도핑한 스칸디아 안정화 지르코니아 (scandia stabilized zirconia, $\mathrm{ScSZ}$ ) 는 Sc 와 $\mathrm{Zr}$ 의 이상적인 크기 일치로 인하여 $\mathrm{YSZ}$ 보다 더 높 은 전도도를 지닌다. ${ }^{13)} 11 \mathrm{~mol} \%$ 를 도핑 하였을 경우에 $850{ }^{\circ} \mathrm{C}$ 에서 1.5 배 높은 이온전도도를 지니나, 활성화 에 너지가 크기 때문에 $500{ }^{\circ} \mathrm{C}$ 이하의 온도에서는 $\mathrm{YSZ}$ 와 유사한 이온전도도를 지닌다.

하지만 낮아진 구동 온도에서 지르코니아계열 전해질 은 높은 활성화 에너지 및 낮은 산소이온 전도도로 인하 여 충분한 성능을 낼 수 없고, 중저온에서 유망한 코발 트 함유 페로브스카이트 공기극 소재 (ex. Lanthanum strontium cobalt ferrite (LSCF)) 와 함께 사용할 수 없 다는 문제점이 있다. ${ }^{9)}$ 따라서, 저온에서도 높은 성능을 내면서 반응을 방지할 수 있는 이중층 전략이 유망하다.

\subsection{2. 세리아계열}

등축정계 형석 구조를 지니는 세륨산화물 $\left(\mathrm{CeO}_{2}\right)$ 은 대표적인 산소이온 전도체로, 산소이온은 산소 빈자리 (oxygen vacancy) 확산 메커니즘을 통해 이동하게 된 다. 하지만, 순수한 $\mathrm{CeO}_{2}$ 는 높은 산소이온 전도를 위한 


\section{특 집 ㅃ 박정화1, 김도엽 ${ }^{1}$, 김경준 ${ }^{1}$, 배경택 ${ }^{1}$, 이강택 ${ }^{+}$}

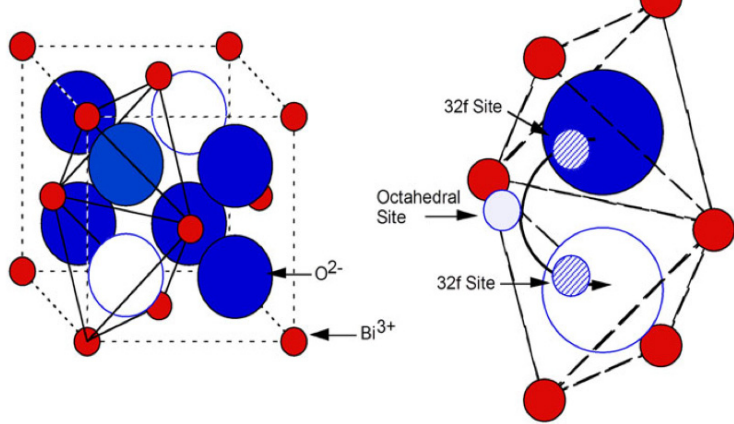

Fig. 4. Conductivity of conventional electrolyte for SOFCs. ${ }^{17)}$

산소 빈자리를 가지고 있지 않기 때문에 $\mathrm{Ce}^{4+}$ 를 이종원 자가 (aliovalent) 도펀트로 치환하여 산소 빈자리를 증 가시킬 수 있다(식 (5)).

$$
2 C e_{c e}^{X}+O_{X}^{O}+M_{2} O_{3} \leftrightarrow 2 M_{C e}^{\prime}+V_{O}^{*}+3 O_{O}^{X}
$$

지르코니아계열 전해질과 마찬가지로 크기 불일치가 가 장 낮은 이온의 경우 전도도가 가장 높으며, 세리아계 열의 경우 $\mathrm{Gd}$ 와 $\mathrm{Sm}$ 이다. $\mathrm{Gd}$ 도핑 세리아 $(\mathrm{Gd}$-doped ceria, $\mathrm{GDC}$ ) 혹은 $\mathrm{Sm}$ 도핑 세리아 ( $\mathrm{Sm}$-doped ceria, $\mathrm{SDC}$ )는 $500{ }^{\circ} \mathrm{C}$ 의 저온에서 약 $0.01 \mathrm{~S} / \mathrm{cm}$ 로 $\mathrm{YSZ}$ $(\sim 0.005 \mathrm{~S} / \mathrm{cm})$ 보다 높은 이온전도도를 지닌다. 양 자 역학적 계산을 통해 도펀트에 따른 결함 연계(defect association)와 이온전도도 사이의 연결을 정량적으로 계산한 결과, $\mathrm{Pm}$ 을 도펀트로 사용할 경우 이온전도도 가 가장 높을 것으로 예측되었다. 하지만 $\mathrm{Pm}$ 은 방사성 원소이기 때문에 도펀트로 사용이 불가능하므로, 두 개 이상의 원소를 동시에 도핑 하는 멀티 도핑 전략을 통해 $\mathrm{Pm}$ 의 유효 이온 반지름을 맞추는 연구가 진행되었다. ${ }^{14}$

다양한 도핑 원소 조합들 중에서도, $\mathrm{Sm}$ 과 $\mathrm{Nd}$ 를 각 $7.5 \%$ 씩 도핑한 경우 $\left(\mathrm{Sm}_{0.075} \mathrm{Nd}_{0.075} \mathrm{Ce}_{0.85} \mathrm{O}_{2-\mathrm{d}}, \mathrm{SNDC}\right)$ 기존 $\mathrm{GDC}$ 보다 약 $30 \%$ 높은 이온전도도를 지녀, 멀티 도핑 전략의 효과를 입증하였다. ${ }^{15)}$ 하지만 이러한 세리 아계열 전해질 소재는 YSZ 와 비교했을 때 이온 전도도 가 높고 활성화 에너지가 낮기 때문에 중/저온형 $\mathrm{SOFC}$ 전해질 소재로 고려되고 있으나, 산소 분압이 낮은 분위 기에 노출되면 $\mathrm{Ce}^{4+}$ 에서 $\mathrm{Ce}^{3+}$ 로 환원 되면서 전자 전도

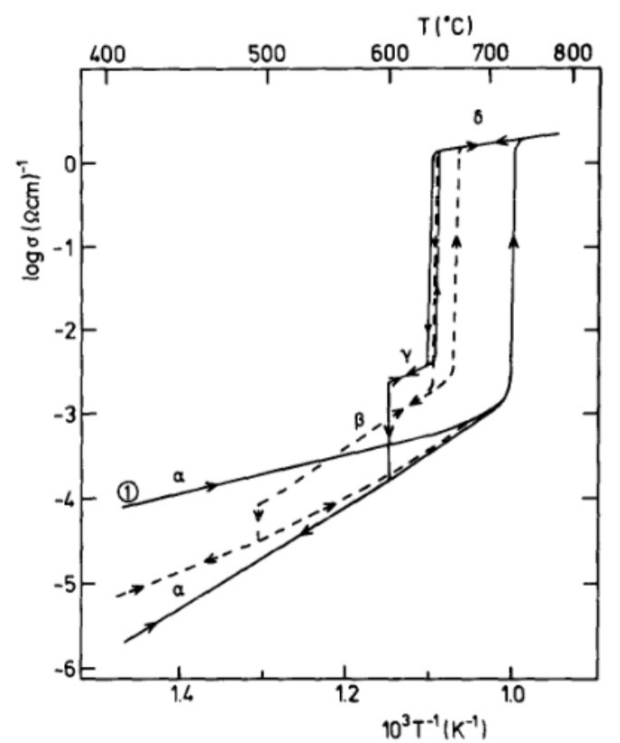

Fig. 5. The total conductivity of $\mathrm{Bi}_{2} \mathrm{O}_{3}$ as a function of reciprocal temperature. ${ }^{18)}$

성이 높아지고 이로 인해 개방 회로 전압 (open circuit voltage, OCV) 가 Nernst 전위보다 낮아지게 된다. 또 한 $\mathrm{Ce}^{4+}$ 의 $0.97 \mathrm{~nm}$ 에서 $\mathrm{Ce}^{3+}$ 의 $1.14 \mathrm{~nm}$ 로 이온 반경 이 증가함으로써 격자가 확장되고 기계적 강도 또한 약 해지게 된다. 따라서 이러한 문제를 해결하기 위해 도핑 세리아 층과 순수한 이온 전도성 물질을 결합한 이중층 전해질 전략이 유망하다. ${ }^{16)}$

\subsection{3. 비스무스계열}

순수한 비스무스산화물 $\left(\mathrm{Bi}_{2} \mathrm{O}_{3}\right)$ 은 지르코니아산화물 과 마찬가지로 동질이상의 특성을 지닌다. 온도에 따라 $\alpha, \beta, \gamma, \delta$ 및 $\varepsilon$ 의 5 개 상으로 존재하고, 특히 $729{ }^{\circ} \mathrm{C}$ 부 터 $824{ }^{\circ} \mathrm{C}$ 영역의 $\delta-\mathrm{Bi}_{2} \mathrm{O}_{3}$ 는 등축정계 형석 구조를 지 닌다. 이때 고유 산소 빈자리 농도가 $25 \%$ 로 높은 산소 이온 전도성을 가진다(Fig. 4). ${ }^{6-9,17)}$

$\delta-\mathrm{Bi}_{2} \mathrm{O}_{3}$ 는 $800{ }^{\circ} \mathrm{C}$ 에서 $1 \mathrm{~S} / \mathrm{cm}$ 에 가까운 전도도를 지 니고, 이는 YSZ 보다 100 배 가량 높은 전도도를 나타낸 다. 하지만 $\delta$ 상은 $729{ }^{\circ} \mathrm{C}$ 아래의 온도에서 산소이온전도 도가 매우 낮은 단사정계 $\left(\alpha-\mathrm{Bi}_{2} \mathrm{O}_{3}\right.$ 상)으로 상 변이되어 전도도가 급격하게 감소하게 된다 (Fig. 5). ${ }^{18)}$

따라서, $\mathrm{Bi}_{2} \mathrm{O}_{3}$ 의 실제 사용을 위해서는 넓은 온도 범 

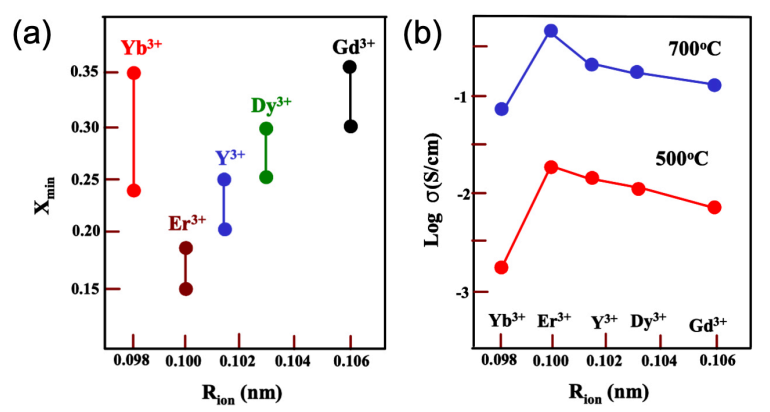

Fig. 6. (a) The plot of minimum dopant concentration of stabilized $-\mathrm{Bi}_{2} \mathrm{O}_{3}$ with various dopant. (b) The ionic conductivity of stabilized $-\mathrm{Bi}_{2} \mathrm{O}_{3}$ with various dopant at 700 and $500{ }^{\circ}{ }^{211}$

위에서 $\delta-\mathrm{Bi}_{2} \mathrm{O}_{3}$ 를 안정화 시키는 것이 필수적이다. 상 변이를 제어하고 높은 이온전도도를 유지하기 위해서 격자내 $\mathrm{Bi}$ 를 란타나이드 ( $\mathrm{Dy}, \mathrm{Er}, \mathrm{Yb}$, etc) 및 희토류 (Sc, Y, etc) 와 같은 도펀트로 일부 치환하는 전략을 통 해, $\delta-\mathrm{Bi}_{2} \mathrm{O}_{3}$ 를 실온까지 안정화 시키는 광범위한 연구 결과가 보고되었다. ${ }^{8,19,20)}$ 안정화시키기 위해서는, $\mathrm{Bi}^{3+}$ 양이온과 도펀트 양이온 사이의 이온 반경이 크게 차이 가 나야한다. 그렇기 때문에, 이온 반지름이 증가할수 록, 도펀트의 함량이 비례적으로 증가하며 결과적으로 전체 이온전도도는 감소하게 된다. 대표적으로, $\mathrm{Er}$ 을 치 환한 어붐 안정화 비스무스 (Er-stabilized bismuth, $\mathrm{ESB}$ ) 로 가장 낮은 도펀트 함량에 따라 높은 이온전도 도를 $\left(0.32 \mathrm{~S} / \mathrm{cm}\right.$ at $\left.700{ }^{\circ} \mathrm{C}\right)$ 보여준다(Fig. 6). ${ }^{21)}$

또한, 더 향상된 이온전도도를 얻기 위해, 세리아계열 전해질과 마찬가지로 멀티 도핑 전략을 통해 다양한 조 합의 도펀트를 동시에 치환하는 연구도 진행되었다. 기 존 단일 도핑 물질 보다 총 도펀트 함량이 더 낮지만, $\delta$ 상이 안정화 되고 순수한 $\delta-\mathrm{Bi}_{2} \mathrm{O}_{3}$ 와 근접하는 큰 격자 파라미터를 지녀 더 높은 이온전도도를 가지는 특성이 있다. 대표적으로 $8 \mathrm{~mol} \%$ 의 $\mathrm{Dy}$ 과 $4 \mathrm{~mol} \%$ 의 $\mathrm{Y}$ 를 $\mathrm{Bi}$ 자 리에 치환한 $\mathrm{Dy}_{0.08} \mathrm{Y}_{0.04} \mathrm{Bi}_{0.88} \mathrm{O}_{1.5}$ (DYSB)가 $700{ }^{\circ} \mathrm{C}$ 에서 $1.1 \mathrm{~S} / \mathrm{cm}$ 의 매우 높은 산소이온 전도도를 갖는다. ${ }^{9)}$ 하 지만 높은 산소이온 전도도에도 불구하고, 비스무스계 열 전해질 소재는 낮은 산소 분압에서 $\mathrm{Bi}^{3+}$ 이 $\mathrm{Bi}$ 금속으 로 환원되기 때문에, $\mathrm{SOFC}$ 전해질로서 안정화 비스무
트 산화물을 사용하기 위해서는, 연료 가스의 환원 분위 기에 대한 노출이 방지되어야 한다. 따라서 환원 분위기 에서 더 안정한 소재를 연료극 쪽에 배치한 이중층 전해 질 전략을 통해 한계를 극복할 수 있다.

\section{1. 4. 란타넘-갈레이트계열}

란타넘-갈레이트 기반 페로브스카이트형 산화물 $\mathrm{ABO}_{3}$ 의 A-site와 B-site 모두를 낮은 산화수를 갖는 원소로 치환시켜 산소 빈자리를 형성해 높은 산소이온 전도성을 얻게 된다. $\mathrm{ABO}_{3}$ 의 구조에서 $\mathrm{A}$ 와 $\mathrm{B}$ 는 각각 $\mathrm{La}$ 와 $\mathrm{Ga}$ 의 서로 다른 양이온을 의미한다. 전형적인 결 정구조는 $\mathrm{A}$ 격자점에는 12 배위수로 연결된 큰 양이온과 $\mathrm{B}$ 격자점에는 6 배위수로 연결된 작은 크기의 양이온으 로 구성되어 진다. $\mathrm{LaGaO}_{3}$ 에서 $\mathrm{A}$-site에는 3가 원소로 구성되어있는 $\mathrm{La}$ 자리에 $\mathrm{Sr}$ 이 고용되고, B-site에는 3 가원소로 구성되어 있는 $\mathrm{Ga}$ 자리에 $\mathrm{Mg}$ 가 치환된 구조가 $\mathrm{SOFC}$ 의 전해질로써 사용되고 있다. 아래 나타낸 주위 산소와의 반응식을 바탕으로 산소나 산소 빈자리에 의 한 전도도를 설명할 수 있다 (식 (6))

$$
\frac{1}{2} \mathrm{O}_{2}+V_{o}=O_{0}^{\chi}+2 h
$$

$\mathrm{Sr}$ 의 이온반경은 $\mathrm{La}$ 의 이온반경과 가장 유사하며 $\mathrm{La}$ 의 치환원소로 가장 적당하지만 $\mathrm{Sr}$ 의 치환효과의 한계 는 $10 \mathrm{~mol} \%$ 로 매우 작다. ${ }^{22)}$ 따라서, A-site인 $\mathrm{La}$ 의 치 환효과의 한계 때문에 산소공공의 증가는 크지 않다. $\mathrm{B}-$ site인 Ga는 알칼리 토금속인 $\mathrm{Mg}$ 과 화학적인 성질 이 유사하지는 않지만 $\mathrm{Ga}$ 의 일부를 $\mathrm{Mg}$ 로 치환 하였을 때 전도도가 크게 향상되었으며, 이는 알칼리토금속의 산소공공을 만들 수 있는 성질 때문에 부가적으로 산소 공공이 형성되었기 때문이며 아래의 식 (7) 으로써 설명 할 수 있다.

$$
A O \rightarrow A_{c}^{\prime}+O_{o}^{\alpha}+\frac{1}{2} O_{2}
$$

여기서 $\mathrm{A}_{\mathrm{c}}$ 는 $\mathrm{La}$ 또는 $\mathrm{Ga}$ 자리에 치환된 유효전하 -1 인 양이온을 나타낸다. 추가적으로, $\mathrm{Mg}$ 가 치환되지 않 은 상태의 $\mathrm{LaSrGaO}_{3}$ 의 경우에는 $\mathrm{Sr}$ 의 치환효과의 한계 는 0.1 인 $10 \mathrm{~mol} \%$ 이었지만 $\mathrm{Mg}$ 가 치환 되었을 때는 약 
특 집 ㅃ 박정화', 김도엽 ${ }^{1}$, 김경준 ${ }^{1}$, 배경택 ${ }^{1}$, 이강택 ${ }^{+}$

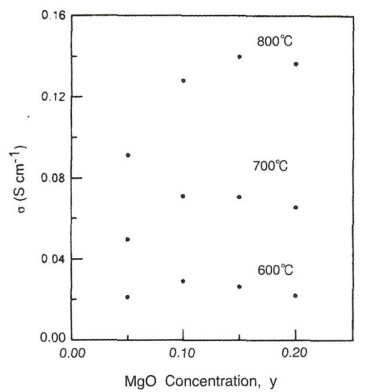

(a)

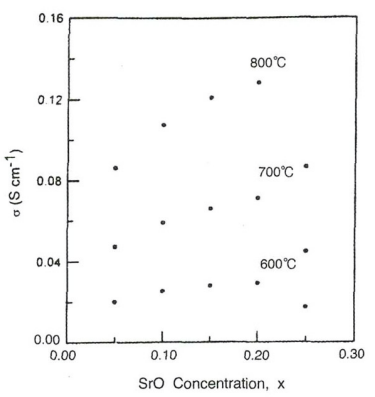

(b)
Fig. 7. The conductivity of $\mathrm{La}_{0.8} \mathrm{Sr}_{0.2} \mathrm{GaxMg}_{1-x} \mathrm{O}_{3}$ samples as a function of strontium and magnesium content.

$20 \mathrm{~mol} \%$ 로 확대된다. 최종적으로, $\mathrm{LaGaO}_{3}$ 의 페로브스 카이트 조성에서 $\mathrm{La}_{0.8} \mathrm{Sr}_{0.2} \mathrm{Ga}_{0.8} \mathrm{Mg}_{0.2} \mathrm{O}_{3-8}(\mathrm{LSGM})$ 가 가 장 높은 산소이온 전도도를 나타나는 것을 확인 할 수 있는 것으로 보고되었다(Fig. 7). ${ }^{22)}$

하지만 LSGM 전해질에서는 다른 구성요소와의 부 반응들로 인해 단전지의 성능을 크게 저하시키는 것으 로 보고된 바 있다. 특히, 연료극 재료로 사용되는 이 온전도체인 세리아, 지르코니아와 심각한 화학 반응성 으로 인한 상안정성의 저하와 $\mathrm{LaSrGa}_{3} \mathrm{O}_{7}, \mathrm{LaSrGaO}_{4}$, $\mathrm{La}_{2} \mathrm{ZrO}_{7}, \mathrm{Sr}_{2} \mathrm{ZrO}_{4}$ 등의 부반응 물질이 생성되면 이들 은 모두 불순물들로 매우 낮은 전기전도도를 가져 전기 전도도손실이 문제점으로 제기되고 있다. 또한, LSGM 과 $\mathrm{NiO}$ 의 반응에 의해 생성되는 $\mathrm{LaNiO}_{3}$ 도 $\mathrm{LSGM}$ 의 페

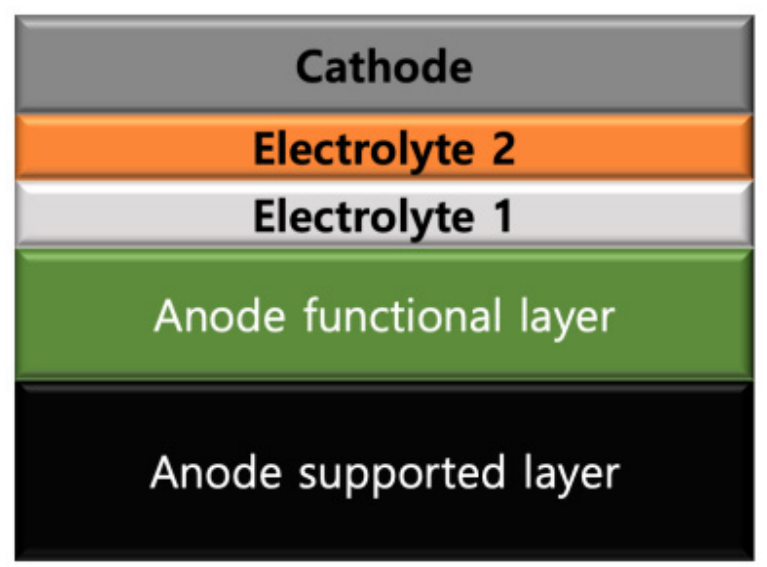

Fig. 8. Schematic diagram of bilayer structure (electrolyte 1, electrolyte 2) of SOFC cell configuration.

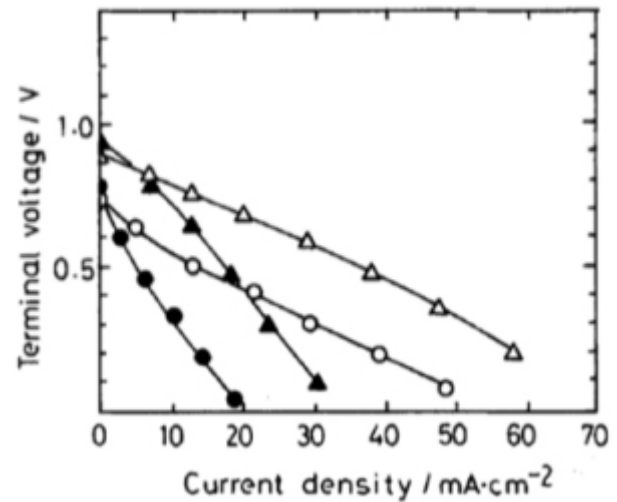

Fig. 9. I-V characteristics of a single layer GDC cell at 600 ${ }^{\circ} \mathrm{C}$ (closed circles) and $700{ }^{\circ} \mathrm{C}$ (open circles) and a YSZ/GDC bilayer cell at $600{ }^{\circ} \mathrm{C}$ (closed triangles) and $700{ }^{\circ} \mathrm{C}$ (open triangles). ${ }^{23)}$

로브스카이트 구조를 불안정하게 만들며 단전지 수명에 악영향을 미치는 것으로 보고 되었다. LSGM전해질과 연료극 사이에 나타나는 문제점을 극복하기 위해서 많 은 연구가 이루어지고 있으며, 세리아계열과 지르코니 아계열의 연료극과 LSGM간의 반응성을 좀 더 면밀히 살펴보고 전해질과 연료극 사이에 완충층을 사용하여 문제점을 해결하고자 한다.

\section{2 이중층 전해질 기술}

이중층 전해질 기술은, 단일 전해질 층과 관련된 단점 을 극복하기 위해, 서로 다른 산화물이 적층된 형태로, 2개의 전해질 층이 고려된다(Fig. 8).

이러한 이중층 기술은, 1988년 Yahiro 그룹에서 처 음으로, 전지의 개방 회로 전압 $(\mathrm{OCV})$ 을 향상시키기 위 해, 세리아계의 단일 전해질층의 전자 차단층으로 지 르코니아계열의 산화물이 가능하다는 것을 보여주었다 (Fig. 9). ${ }^{23)}$

이 후, 다수의 그룹들은 다양한 산화물을 이용하여 최 상의 특성을 조합하는 연구를 진행하였으며, 대표적으 로 (i ) $\mathrm{ZrO}_{2}-\mathrm{CeO}_{2}$ (지르코니아/세리아), (ii) $\mathrm{ZrO}_{2}-$ $\mathrm{Bi}_{2} \mathrm{O}_{3}$ (지르코니아/비스무스 산화물), (iii) $\mathrm{CeO}_{2}-\mathrm{Bi}_{2} \mathrm{O}_{3}$ (세리아/비스무스 산화물), (iv) $\mathrm{CeO}_{2}-\mathrm{LaGaO}_{3}$ (세리 아/란타넘-갈레이트) 시스템이 있다. 하지만, 이중층 

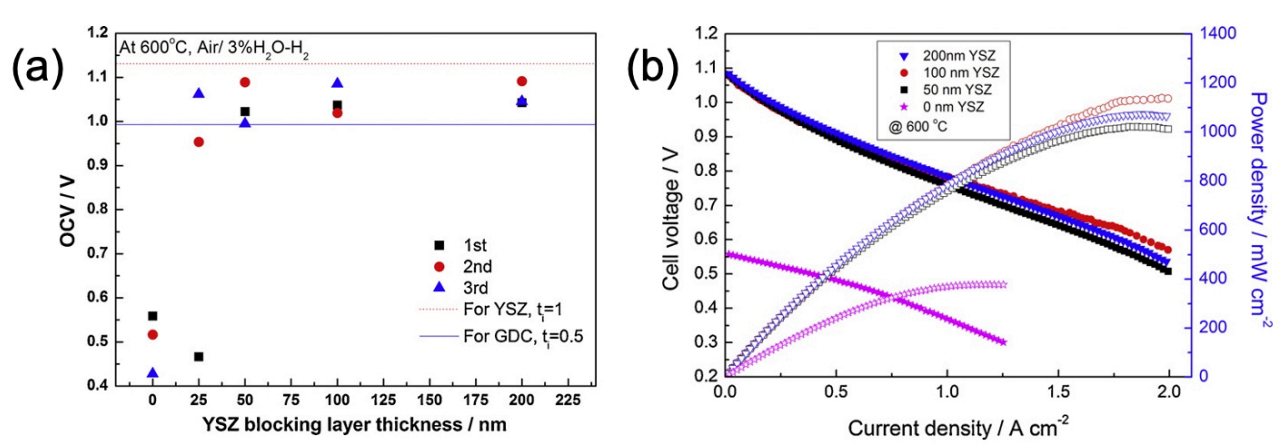

Fig. 10. (a) OCV values of the TF-SOFCs as a function of the YSZ blocking layer thickness. (b) $\mid-V-P$ curves of the cells with various YSZ blocking layer thicknesses. ${ }^{27}$

전해질은 수축 호환성, 구성물 간 상호 확산 및 이차 상 형성, 열팽창 계수 정합성과 같이 여전히 해결해야 할 다양한 문제들이 있다.

\section{2.1. 지르코니아/세리아 이중층 전해질}

지르코니아/세리아 이중층은 지르코니아계 전해질이 지닌 뛰어난 안정성과 낮은 전도성을 세리아계 전해질 의 높은 산소이온 전도성 및 공기극과 낮은 반응성을 이 용한 것이다. 이 시스템을 적용하여 얻을 수 있는 이점 은 크게 두 가지가 있다. 먼저 (i) 세리아계 전해질의 누 설 전류를 최소화 할 수 있고, (ii) 지르코니아계 전해질 과 코발트 함유 공기극과 반응을 막을 수 있다. 지르코니 아/세리아 이중층 전해질을 $\mathrm{SOFC}$ 에 적용하여 누설 전류 를 최소화하기 위해, 세리아 층의 위치와 지르코니아계 전해질의 적합한 두께를 평가하는 많은 연구가 진행되어 왔다. 이를 위해 셀 구동 조건에서 두 전해질 계면의 산 소 분압 의존성을 평가 기준 중 하나로 잡았다. Marques 그룹과 Virkar 그룹은 세리아 층의 위치를 결정하기 위 해 YSZ/GDC와 GDC/YSZ 이중층 전해질의 산소 투과 성 (oxygen permeability) 과 화학 포텐셜 (chemical potential)을 각각 측정하였고, 두 연구 모두 YSZ 위치에 상관없이 누설 전류를 차단한다는 것을 발견했다. ${ }^{24}{ }^{25)}$ 특 히, Virkar 그룹의 연구 결과에 따르면 GDC가 연료극 쪽 에 위치할 경우 3 배 이상 높은 최대 출력 밀도를 나타냈 다 (0.52 vs. $\left.0.14 \mathrm{~W} / \mathrm{cm}^{2} @ 650{ }^{\circ} \mathrm{C}\right){ }^{25)}$

전해질 두께에 대한 연구로 Yoo 그룹은 전자 누설 전
류를 차단하기 위한 YSZ/GDC의 최소 두께 비율은 약 $10^{-4}$ 로, 이때 이온 전도도는 GDC와 비슷하게 유지된 다. ${ }^{26)}$ Fig. 10은 YSZ 두께에 따른 SOFC 단전지의 OCV 값과 성능을 보여준다. YSZ 층의 적용은 두께에 상관 없이 OCV를 $0.55 \mathrm{~V}$ 에서 $\sim 1.1 \mathrm{~V}$ 로 실질적으로 증가시 키고, 셀 성능 또한 $0.377 \mathrm{~W} / \mathrm{cm}^{2}$ 에서 $1.2 \mathrm{~W} / \mathrm{cm}^{2}$ 로 3 배 정도 높아진 결과를 보였다. ${ }^{27)}$

앞서 GDC가 연료극 쪽에 위치하면 더 높은 성능을 지 닌다는 연구 결과도 있으나, 최근 연구의 대부분은 세 리아계 전해질이 공기극 쪽에 위치한 지르코니아계/세 리아계 이중층 구조에 초점을 두고 있으며 이는 코발트 함유 공기극을 사용하기 위함이다. 대표적인 코발트 함 유 공기극은 $\mathrm{LSCF}$ 로, 고온에서 $\mathrm{YSZ}$ 와 반응하여 낮은 산소이온 전도도를 지닌 이차상 (ex. $\mathrm{SrZrO}_{3}$ ) 을 생성 한다. 세리아계 전해질은 $\mathrm{LSCF}$ 와 YSZ의 버퍼층의 역 할을 하여 두 소재의 반응을 막지만, 다공성의 세리아 계 이중층에서는 $\mathrm{Sr}$ 이 그레인 표면을 따라 확산되어 $\mathrm{Zr}$ 와 반응을 하게 된다. 따라서, 세리아계 전해질은 치밀 한 구조를 지녀야 원소의 확산을 막을 수 있지만, 치밀 도를 달성하기 위해서는 $1400{ }^{\circ} \mathrm{C}$ 이상의 고온에서 소결 이 필수불가결하다. 하지만 고온 소결은 이온 전도도가 낮은 cerium zirconate를 형성하여, $\mathrm{SOFC}$ 의 성능이 떨 어지게 된다. ${ }^{28)}$ 치밀도를 높이면서 두 전해질 간의 반응 성을 최소화하기 위하여 다양한 연구가 진행되어 왔고, 크게 (i) 증착법 다양화 및 (ii) 소결조제의 적용이 있 다. 우선, 증착법에 대해 살펴보자면 Gauckler 그룹은 
특 집 표 박정화', 김도엽, 김경준, 배경택1, 이강택2
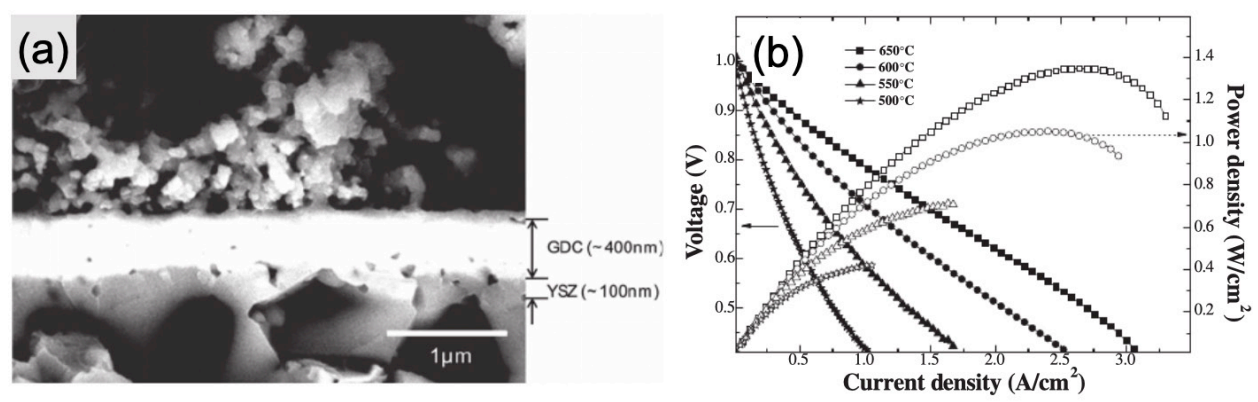

Fig. 11. (a) SEM image of a YSZ (100 nm)/GDC (400 nm) bilayer electrolyte deposited by CSD. (b) Voltage and power density versus current density. ${ }^{30)}$

pulsed laser deposition (PLD)를 이용하여 $600 \mathrm{~nm}$ 이하의 치밀한 $\mathrm{GDC}$ 층을 성공적으로 적층하였다. ${ }^{29)}$ 하 지만 PLD와 같은 진공 증착법은 비용이 비싸기 때문에 Lee 그룹에서는 비용 면에서 효과적이고 확장성이 좋은 chemical solution deposition (CSD)를 이용하여 400 $\mathrm{nm}$ 의 얇고 치밀한 $\mathrm{GDC}$ 를 적층하였고, $650{ }^{\circ} \mathrm{C}$ 에서 $1.4 \mathrm{~W} / \mathrm{cm}^{2}$ 의 높은 성능을 달성하였다 (Fig. 11). ${ }^{30)}$ 다 른 연구로 Paik 그룹은 손쉬운 spin coating 기술을 이 용하여 $1200{ }^{\circ} \mathrm{C}$ 의 온도에서도 치밀한 $\mathrm{GDC}$ 층을 적층 하고 장기 구동 평가를 진행했을 때도 이차상 생성 없이 안정한 결과를 보였다. ${ }^{31}$

소결조제를 이용하여 세리아계열 전해질의 치밀도를 향상시키는 방법은 간단하면서도 효과적인 방법이다. 예를 들어 Barnet 그룹은 대표적인 소결조제 중 하나 인 $\mathrm{Fe}_{2} \mathrm{O}_{3} 1 \mathrm{~mol} \%$ 를 $\mathrm{YSZ}$ 와 $\mathrm{GDC}$ 에 첨가하여 공소결 온
도에 따른 미세구조 및 성능 평가를 진행하였다. 그 결 과 $1250{ }^{\circ} \mathrm{C}$ 에서 공소결 진행한 샘플이 다른 온도와 비교 했을 때 가장 높은 성능을 보여주었으며, 소결조제의 첨 가가 $\mathrm{GDC}$ 의 치밀도를 향상시키는 뿐만 아니라 전해질 층에서 전자 전도도 일으키지 않음을 확인하였다. ${ }^{28)}$ 또 한 Bassat 그룹은 $\mathrm{Li}, \mathrm{Cu}, \mathrm{Zn}$ 질산염 수용액으로 $\mathrm{GDC}$ 분말을 변형하여 소결온도를 $1050{ }^{\circ} \mathrm{C}$ 까지 낮추면서 치 밀도를 향상시켰다. ${ }^{32)}$ 여기에서 나아가, 소결조제 법 을 나노 공정과 결합하여 $1200{ }^{\circ} \mathrm{C}$ 에서 성공적으로 치밀 한 $\mathrm{GDC}$ 를 형성한 예시도 있다. 이 연구에서는 소결조 제 역할을 하는 $\mathrm{Co}$ 를 함께 도핑한 $\mathrm{GDC}$ 와 나노 크기의 $\mathrm{GDC}$ 를 활용하여 기공률이 $5.2 \%$ 에 불과한 $\mathrm{GDC}$ 층을 제작하였으며, 대면적 셀에도 적용하여 면적 확장의 가 능성을 보여주었다. ${ }^{33)}$

적층법과 소결조제를 활용한 예 이외에도, 냉간정수
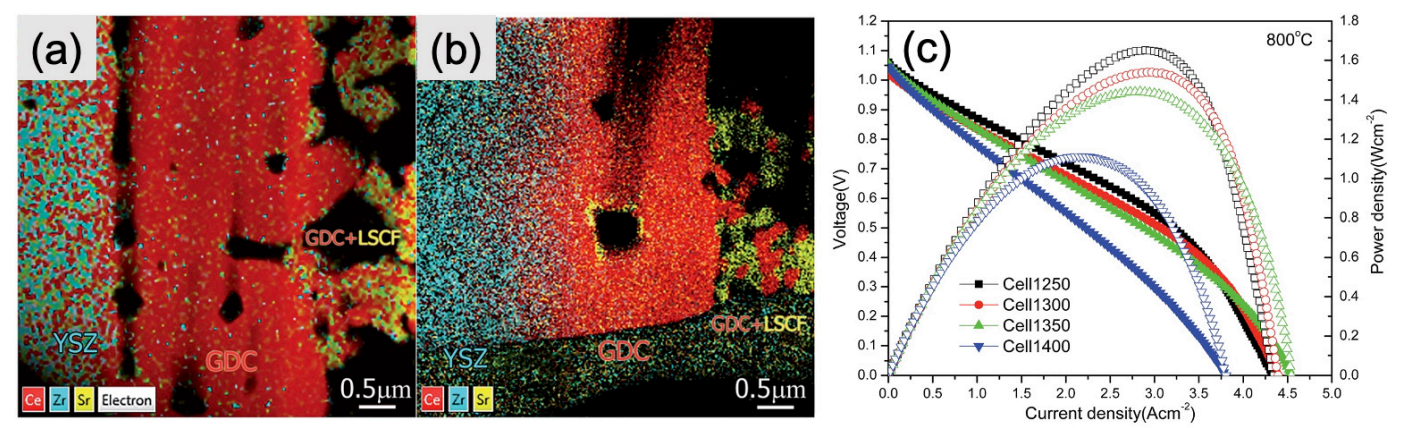

Fig. 12. EDS element mapping of the cell fired at (a) $1250{ }^{\circ} \mathrm{C}$ and (b) $1400{ }^{\circ} \mathrm{C}$. (c) I-V-P curve of cells with different co-firing temperatures. ${ }^{28)}$ 

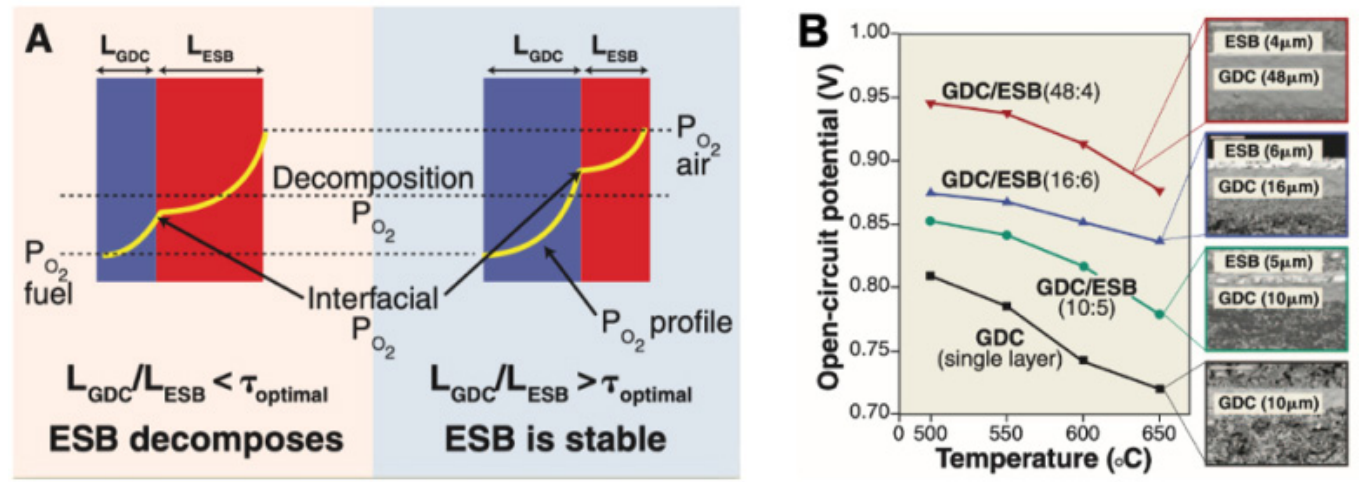

Fig. 13. Schematicof $\mathrm{Bi}_{2} \mathrm{O}_{3} / \mathrm{CeO}_{2}$ bilayer concept demonstrating(a) the effect of relative thickness on interfacial oxygenpartial pressure and ESB stability (b) Effect oftotal thickness and thickness ratio of bilayered electrolyte on OCV.1)

압성형 (cold isostatic pressing, CIP) 공법을 적용하여 치밀한 $\mathrm{GDC}$ 층을 적층한 예가 있다. Paik 그룹은 적층 된 $\mathrm{GDC}$ 를 $\mathrm{CIP}$ 를 이용하여 수직방향으로 우선 압축하 고, $1250{ }^{\circ} \mathrm{C}$ 에서 소결하면서 측면방향으로 수축하여 결 과적으로 $2.5 \%$ 이내의 기공률을 지니는 GDC 층을 얻 었고, 장기 안정성 또한 우수한 결과를 보였다. ${ }^{34)}$

\section{2. 2. 세리아/비스무스 이중층 전해질}

세리아/비스무스 이중층 전해질은, 비스무스계열 전 해질의 높은 이온 전도도와 세리아계열 전해질이 지닌 공기극 물질과 반응성이 낮고 연료 안정성이라는 장점 이 결합된 시스템이다. 이 시스템에서 세리아계열 전해 질은 낮은 산소 분압의 연료극 분위기에서 $\mathrm{Ce}^{4+}$ 가 $\mathrm{Ce}^{3+}$ 로 환원되며 비스무스 산화물 기반 전해질은 동일 분위 기에서 금속 $\mathrm{Bi}$ 로 분해되는 문제점을 가진다. 따라서 두 개의 시스템을 결합하여 문제점을 해결하기 위해서 는, $\mathrm{Bi}_{2} \mathrm{O}_{3}$ 기반 전해질이 공기극 쪽에 위치해야한다. 비 스무스계열 전해질 층은 세리아계열 전해질 층에서의 전자 흐름을 막아주며, 충분히 두꺼운 세리아계열 전해 질 층은 비스무스계열 전해질이 $\mathrm{Bi}$ 금속으로 분해되는 것을 방지해 준다. 비스무스계열 전해질 층이 공기극과 맞닿아 있는 것의 한 가지 추가적인 장점은 세리아계열 전해질 보다 전해질 표면에서의 산소 흡착 반응이 더욱 활발하다는 것이다. 따라서 비스무스계열 전해질을 전 해질/공기극 계면 사이에 사용하는 것은 공기극 활성화
에너지를 감소시키는 전략이 될 수 있다. ${ }^{35,36)}$

세리아/비스무스 이중층 전해질은, 지르코니아/세리 아 이중층 전해질과는 다르게, 비스무스계열 전해질 층 의 낮은 녹는점 $\left(\sim 800{ }^{\circ} \mathrm{C}\right)$ 으로 인해 연료극과 두 개의 전해질 층을 동시에 소결할 수 없다. 대안으로 이들 이 중층 시스템은 (i) 높은 온도 $\left(\right.$ 약 $1400{ }^{\circ} \mathrm{C}$ )에서 연료 극과 세리아계열 전해질 층을 동시에 공소결하는 종래 의 방법을 적용한 뒤, 비스무스계열 전해질층을 연속적 으로 적층하고 $800{ }^{\circ} \mathrm{C}$ 이하에서 소결하는 방법과 저온 physical vapor deposition (PVD) 공법을 사용하여 증 착하는 방법이 있으며, (ii) 2 개의 층을 연속으로 $\mathrm{PVD}$ 방식으로 적층하는 방법이 있다.

지르코니아/세리아 이중층 전해질 시스템과 비교하 여, 이들 이중층 전해질 시스템은 환원 분위기에서 세리 아계열 전해질 층의 누설 전류 특성으로 인하여 전체 두 께 및 두께 비율의 관점에서 훨씬 엄격한 두께 최적화 가 필요하다. 즉, 더 얇은 전해질을 사용하여 오믹 저항 을 을 감소시키는 것과, 더 두꺼운 전해질을 사용함으로 써 OCV를 향상시키는 것 사이의 균형을 유지하는 것이 중요하다. Fig. 13은 이중층 계면에서 계면 산소 분압을 제어하기위한 전해질간의 상대적인 두께 비율에 대한 개념도를 보여주고 있다. ${ }^{1)}$

예를 들어, Wachsman 그룹은 연료극지지형 셀에서 $\mathrm{OCV}$ 값에 대한 $\mathrm{ESB} / \mathrm{GDC}$ 이중층 두께에 대한 연구를 진행했다. 총 두께 및 두께 비율을 변경하면서, $500{ }^{\circ} \mathrm{C}$ 
(a)

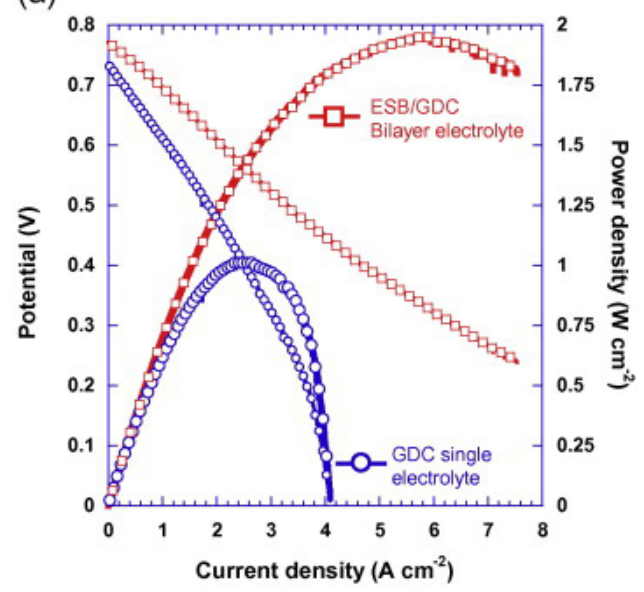

Fig. 14. I-V chracteristics of the fuel cell samples with GDC single-layer and ESB/GDC bilayer electrolyte at 650 ${ }^{\circ} \mathrm{C} .{ }^{36)}$

에서 이론적 $\mathrm{OCV}$ 값을 얻을 수 있었다. $48 \mathrm{um}$ 두께의 $\mathrm{GDC}$ 를 사용하게 되면 $\mathrm{OCV}$ 가 $0.95 \mathrm{~V}$ 로 향상되지만, 해당 값은 여전히 이론값에 도달하지는 못한다. 이는 내 부 단락이 여전히 어느 정도 존재하며 이론적 OCV를 달 성하기 위해서는 층간 두께의 추가적인 증가가 필수적 이라는 것을 시사한다. ${ }^{1)}$

Fig. 14 는 $650{ }^{\circ} \mathrm{C}$ 에서 $\mathrm{GDC}$ 단일 전해질과 $\mathrm{ESB} / \mathrm{GDC}$ 이중 전해질이 적용된 샘플의 $\mathrm{I}-\mathrm{V}$ 그래프를 보여주고

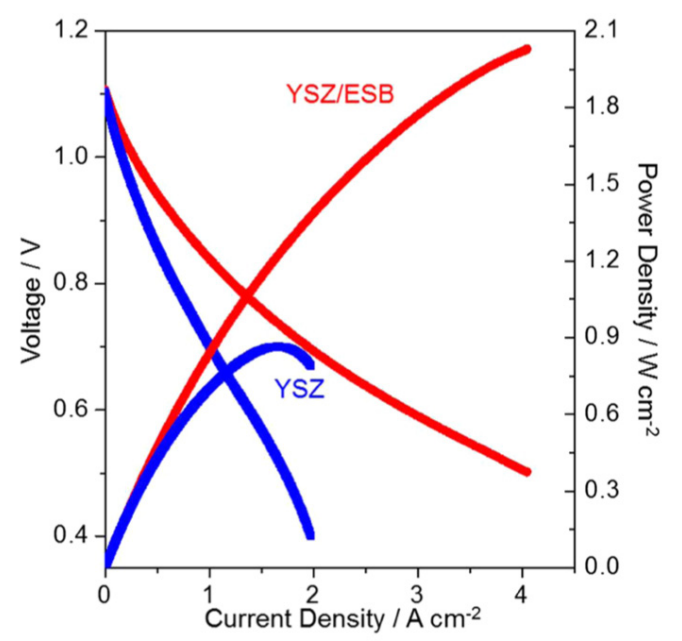

Fig. 15. I-V chracteristics of YSZ single layer cell structure (blue) and YSZ/ESB bilayer cell structure (red) of SOFC cells at $650{ }^{\circ} \mathrm{C} .{ }^{37)}$
있으며 이를 통해 비스무스/세리아 이중층 전해질이 기 존 대비 2 배 이상의 성능을 나타낸다는 것을 명백히 알 수 있다. ${ }^{36)}$

따라서, 비스무스계열 전해질 기반 이중층 전해질 기 법의 적용은 더 낮은 온도에서도 작동할 수 있는 기능을 갖춘 고성능 $\mathrm{SOFC}$ 개발의 단초를 제공할 수 있으며, 고 분자 전해질 연료 전지의 강력한 경쟁자로 부상할 수 있 는 강력한 잠재력을 가지고 있음을 알 수 있다.

\section{2. 3. 지르코니아/비스무스 이중층 전해질}

최근, Lee 그룹에 의해 보고된 연구에 의하면, $700{ }^{\circ} \mathrm{C}$ 이하의 구동 온도에서 지르코니아/비스무스 계열 이중 층 전해질 구조를 (YSZ/ESB) 개발하여, 기존 지르코니 아 단일 전해질 기반의 $\mathrm{SOFC}$ 성능 대비 $140 \%$ 가량 향 상시켰다(Fig. 15). ${ }^{37)}$

$\mathrm{ESB}$ 전해질은 YSZ 전해질에 비해, 빠른 산소이온전 도성과 산소이온함입율 (oxygen ion incorporation)을 가지며, 이로 인해 공기극과의 계면에서 산소환원반응 을 향상시킬 수 있다. 또한, YSZ 전해질의 경우, 연료극 의 환원 분위기로부터 화학적/구조적으로 안정하기 때 문에, $\mathrm{ESB}$ 전해질이 환원 분위기로부터 분해되는 현상 을 방지할 수 있다. 이는 $\mathrm{ESB}$ 가 금속 $\mathrm{Bi}$ 로 환원되는 것 을 막을 수 있으며, 높은 OCV를 확보함으로써 $\mathrm{SOFC}$

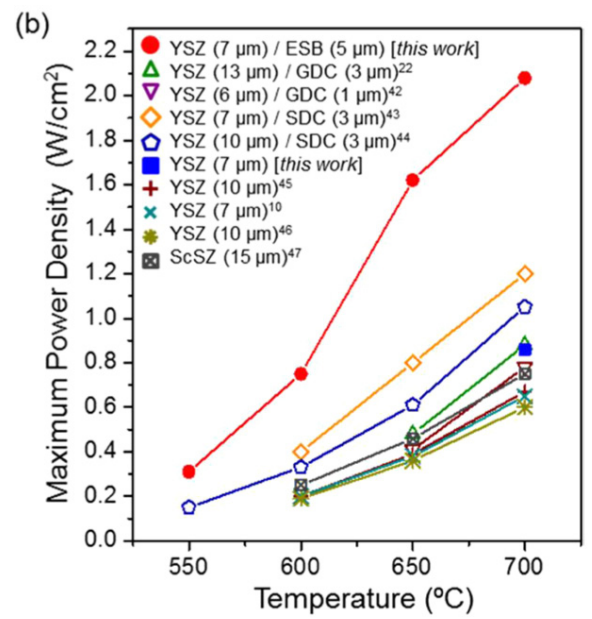

Fig. 16. I-V Comparison of MPDs with various SOFC cell configuration based on YSZ electrolyte. ${ }^{37}$ 
의 높은 전압 효율을 극대화할 수 있을 것으로 예상되었 다. $\mathrm{YSZ} / \mathrm{ESB}$ 이중층 기반의 $\mathrm{SOFC}$ 성능은 $650{ }^{\circ} \mathrm{C}$ 에서 $\sim 1.62 \mathrm{~W} / \mathrm{cm}^{2}$ 의 높은 최대 출력 밀도를 기록하였고, 이 는 YSZ 전해질 기반의 다양한 SOFC 단전지의 성능대비 최대 330\% 가량 향상된 성능을 나타낸다(Fig. 16).

여전히, 화학적 및 구조적인 최적화가 요구되지만, 지 르코니아/비스무스 산화물 이중층 기술은 낮은 구동 온 도에서 효율적이고 높은 전력 밀도를 달성할 수 있는 매 우 유망한 이중층 전해질 구조로 고려된다.

\section{2. 4. 세리아/란타넘-갈레이트 이중층 전해질}

LSGM의 복잡한 양이온 조성물 $(\mathrm{La}, \mathrm{Sr}, \mathrm{Ga}, \mathrm{Mg})$ 로 인해, 이들 화합물이 약 $1500{ }^{\circ} \mathrm{C}$ 보다 낮은 온도에서 하 소 되면 다수의 중간상이 형성 될 수 있다. 따라서, 높은 순도의 단일상 LSGM을 획득하기 위해, 매우 높은 소결 온도에서의 하소는 불가피하다. 또한, 전지를 제조하기 위한 온도에서, LSGM의 높은 화학적 반응성은 LSGM 기반 고체산화물 연료전지의 제조를 어렵게 만든다. LSGM기반 고체산화물 연료전지는 보통 $\mathrm{NiO}$ 와 GDC 로 만들어진 연료극이 통상적으로 사용된다. 두 화합물 모두 고온에서 소결되는 동안 LSGM 내에서 $\mathrm{La}^{3+}$ 이온 은 전해질-연료극 계면을 통해 확산되어 계면에서 $\mathrm{La}-$ $\mathrm{Sr}-\mathrm{Ga}-\mathrm{O}$ 이차상 및 $\mathrm{LaNiO}_{3}$ 같은 매우 낮은 전도도를 가지는 화합물이 형성된다. 이를 해결하기 위해서 완충 층 도입을 통한 LSGM 기반 연료전지가 많은 연구가 시 행되어져 왔다. 전해질과 연료극 사이의 완충층 재료는 이온전도가 지배적인 이온전도체 혹은 이온/전자 혼합 전도체여야 하며, 두 구성요소 간의 계면반응 및 그에 따른 이차상의 생성을 억제할 수 있어야 한다.

예를 들어, 음극 재료는 물론 완충층 재료로도 많이 활용되고 있는 지르코니아계 전해질을 완충층으로 적용 시에 $\mathrm{LaSrGa}_{3} \mathrm{O}_{7}, \mathrm{LaSrGaO}_{4}, \mathrm{La}_{2} \mathrm{ZrO}_{7}, \mathrm{Sr}_{2} \mathrm{ZrO}_{4}$ 등의 높은 저항을 나타내는 화합물을 다량 발생하는 것으로 나타내었다. ${ }^{38)}$ 세리아계열 전해질중 대표적인 $\mathrm{SDC}$ 또 는 GDC의 경우 LSGM 전해질로부터 일부 $\mathrm{La}^{3+}$ 이온 확 산을 차단하여 저항성이 큰 부반응 물질의 생성을 억제 하는 것으로 보였지만, 그 효과가 미비하여 다른 대응책

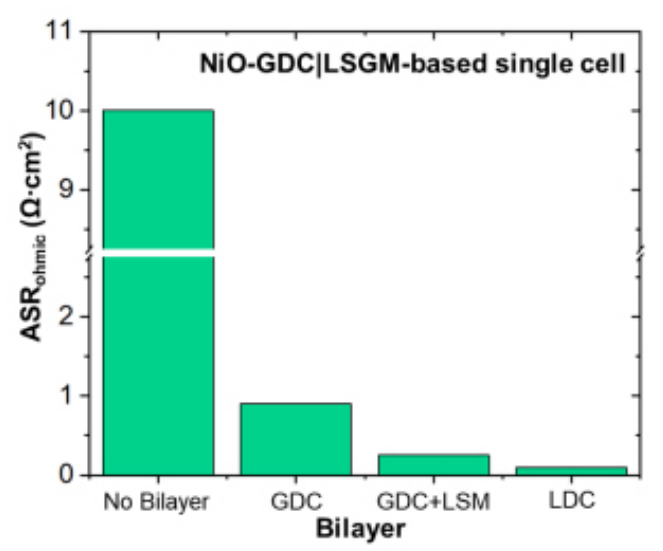

Fig. 17. Ohmic Area Specific Resistance(ASR) of LSGM based single cell according to different bilayers at $750{ }^{\circ} \mathrm{C}$.

이 필요할 것으로 밝혀졌다. ${ }^{39)} \mathrm{LDC}$ (La-doped Ceria) 는 전기전도도가 충분히 높을 뿐만 아니라, $\mathrm{La}$ 의 비율 이 40\%일 경우 LSGM전해질 내 La의 화학적 포텐셜을 유지시켜 전해질에서 음극으로의 La 확산을 억제한다고 보고된 바 있다(Fig. 17). ${ }^{40,41)}$

이에 따라, 채택 된 접근법은 $\mathrm{LDC}$ 를 $\mathrm{LSGM}$ 전해질 과 연료극 지지체 사이의 완충층으로서 사용하는 $\mathrm{LDC} /$ LSGM 이중층에 기초한 시스템이었다.

예를 들어, Lee 그룹에서는 $\mathrm{LDC}$ 완충층이 삽입된 단 전지와 삽입되지 않은 단전지의 성능측정을 비교한 연 구 결과를 보고 하였다. ${ }^{42)} \mathrm{LDC}$ 완충층이 없는 단전지의 경우 $700{ }^{\circ} \mathrm{C}$ 에서 OCV는 $0.42 \mathrm{~V}$ 였고, $0.40 \mathrm{~mW} / \mathrm{cm}^{2}$ 의 매우 낮은 최대 출력 밀도 보였다. 이러한 낮은 $\mathrm{OCV}$ 값과 최대 출력 밀도는 완충 층이 없는 상태에서 LSGM 전해질과 음극이 직접 반응함으로써 저항 값이 큰 $\mathrm{La}-$ $\mathrm{Sr}-\mathrm{Ga}-\mathrm{O}$ 이차상이 계면에 연속적으로 생성됨에 의 한 것으로 판단된다. $\mathrm{LDC}$ 완충층이 삽입된 단전지의 경 우 $700{ }^{\circ} \mathrm{C}$ 에서 $\mathrm{OCV}$ 는 $0.64 \mathrm{~V}$, 최대 출력 밀도는 223 $\mathrm{mW} / \mathrm{cm}^{2}$ 로 측정되었으며, 완충층이 없는 단전지의 최 대출력밀도에 비해 약 400 배의 높은 값을 보였다. 이는 $\mathrm{LDC}$ 완충층이 계면 부근 LSGM의 La 고용량을 유지시 켜 전해질의 분해를 막고 상안정성에 기여했기 때문인 것으로 고려된다. 또 다른 연구로는, $\mathrm{Bi}$ 등의 연구팀에서 $\mathrm{NiO} / \mathrm{GDC}$ 연료극 지지체 상단에 $100 \mu \mathrm{m} \mathrm{LDC} / \mathrm{LSGM}$ 
이중층 필름을 건식 프레싱함으로써 단위 셀을 제조하 였다. ${ }^{43)}$ 제작된 단전지는 각각 800 도 및 $700{ }^{\circ} \mathrm{C}$ 에서 1.1 및 $0.56 \mathrm{~W} / \mathrm{cm}^{2}$ 를 달성 하였다. 추후 연구로써, $\mathrm{Bi}$ 연 구팀은 $\mathrm{LDC} / \mathrm{LSGM}$ 이중층 막의 두께를 $65 \mu \mathrm{m}$ 로 감 소시켜 향상된 셀 성능 (800 및 $700{ }^{\circ} \mathrm{C}$ 에서 1.565 및 $\left.0.843 \mathrm{~W} / \mathrm{cm}^{2}\right)$ 을 보고 하였다. ${ }^{44)}$ 이상의 결과로부터, LSGM계 음극지지형 단전지의 출력성능은 전해질과 전 극 계면에서의 반응층 및 LDC/LSGM 이중층 막의 두 께에 의해 직접적인 영향을 받는다는 것을 알 수 있었으 며, 이 계면에 $\mathrm{LDC}$ 완충층을 삽입하면 전해질 내의 $\mathrm{La}$ 고용량을 유지시켜 저항 값이 큰 계면 반응층 생성을 억 제함으로써 단전지의 내부저항을 최소화하고 성능저하 를 방지할 수 있음을 확인하였다. 한편 단전지 성능의 최 적화를 위해서는 양극/전해질 계면의 열응력 (thermal stress) 개선, 연료극에서 전해질로의 $\mathrm{Ni}$ 확산 제어 등 추가적인 문제들이 해결되어야 할 것으로 보인다.

\section{3. 결론}

고체산화물 연료전지는 친환경, 높은 발전효율 및 에 너지효율, 고온 구동에 따른 다양한 연료 선택성이 가 능한 장점으로 차세대 에너지 변환 기술로 각광 받고 있 다. 하지만, 고온에서의 성능 열화, 내구성 저하와 같은 문제는 극복해야할 연구 대상이 되고 있다. 따라서, 구 동 온도를 중저온 영역 $\left(\left\langle 700{ }^{\circ} \mathrm{C}\right)\right.$ 으로 낮추는 노력이 계 속되고 있으며, 극복해야할 핵심 요소 중 하나인, 전해 질 소재 및 구조 개발이 대상이 되고 있다. 이중층 전해 질 전략은 단일 전해질 사용과 관련된 단점을 극복할 수 있으며, 중저온 영역에서 고체산화물 연료전지의 성능 을 향상시켜주는 중요한 전략으로 볼 수 있다. 일반적 인 전해질 재료로서, 지르코니아 및 세리아계열의 일반 적인 형성 구조의 이온전도체 뿐만 아니라, 페로브스카 이트 형태의 란타념-갈레이트계열의 차세대 전해질 소 재에 대한 연구가 많이 이루어지고 있다. 하지만, 지르 코니아 계열의 전해질의 경우 낮은 구동 온도에서 급격 하게 감소하는 이온 전도성과, 세리아계열에서의 $\mathrm{SOFC}$ 구동 조건에서 내부 누설 전류에 의한 OCV 감소, 전력
손실을 야기한다. 또한, 비스무스계열의 경우 연료극 환 원 분위기에서 비스무스 금속으로 분해되는 문제점과, 란타넘-갈레이트 산화물에서의 다른 전극 구성 원소와 의 화학적 반응성으로, 단일 소재로서의 전해질 한계성 이 단점으로 지적되어 왔다.

이러한, 단일 소재들의 한계성을 극복하기 위해 다양 한 산화물 간의 이중층 전해질 시스템이 개발되었으며, 이는 중저온 영역에서 향상된 $\mathrm{SOFC}$ 성능을 이끌어 냈 다. 지르코니아 계열의 낮은 이온전도성은 세리아 및 비 스무스 산화물과의 이중층을 통해 단점을 보완할 수 있 으며, 세리아 및 비스무스계열의 누설 전류와 화학적 불 안정성 역시, 다른 산화물 층에 의한 전류 및 분위기 차 단으로 $\mathrm{OCV}$ 를 증가 시킬 수 있는 것으로 나타났다.

향후, 실제 $\mathrm{SOFC}$ 에 적용 되기 위해서는, 여전히, 전 해질 간 두께 및 비율, 그리고 구조적 최적화가 필요하 며, 특히 전해질/전극 계면에서의 화학적/물리적 반응 성, 장기 구동시의 안정성 문제 등의 구성 향상 연구는 우선적으로 이루어져야 한다.

\section{4. 감사의 글}

이 논문은 2020년도 정부 (과학기술정보통신부)의 재원 으로 한국연구재단의 지원을 받아 수행된 연구임. (NRF2019M3E6A1103944, NRF-2017M1A2A2044931)

\section{REFERENCES}

1. E. D. Wachsman, K. T. Lee, "Lowering the temperature of solid oxide fuel cells", Science, 334 [6058] 935-939 (2011).

2. S.-H. Choe, W.-S. Park, "고체산화물 연료전지 (SOFC) 핵심 소재 및 단전지 연구개발", Ceramist, 13 [4] 21-14 (2010).

3. H. - Y. Lee, B. - K. Kang, H. - C. Lee, Y. $-W$. Heo, J.-J. Kim, J.-H. Lee, "Effects of Co-doping on Densification of $\mathrm{Gd}$-doped $\mathrm{CeO}_{2}$ Ceramics and Adhesion Characteristics on a Yttrium Stabilized Zirconia Substrate", $J$. Korean Ceram. Soc., 55[6] 576-580 (2018).

4. H. -W. Lee, H.-I. Ji, J.-H. Lee, B. -K. Kim, K. 
J. Yoon, J.-W. Son, "Powder Packing Behavior and Constrained Sintering in Powder Processing of Solid Oxide Fuel Cells (SOFCs)", J. Korean Ceram. Soc., 56 [2] 130-145 (2019).

5. K. T. Lee, H. S. Yoon, E. D. Wachsman, "The evolution of low temperature solid oxide fuel cells", J. Mater. Res., 27 [16], 2063-2078 (2012).

6. N. Mahato, A. Banerjee, A. Gupta, S. Omar, K. Balani, "Progress in material selection for solid oxide fuel cell technology: A review", Prog. Mater. Sci., 72 141-337 (2015).

7. D. W. Joh, J. H. Park, D. Y. Kim, B.-H. Yun, K. T. Lee, "High performance zirconia-bismuth oxide nanocomposite electrolytes for lower temperature solid oxide fuel cells", J. Power Sources, 320 267-273 (2016).

8. B.-H. Yun, C.-W. Lee, I. Jeong, K. T. Lee, "Dramatic enhancement of long-term stability of erbia-stabilized bismuth oxides via quadrivalent Hf doping" Chem. Mater., 29 10289-10293 (2017).

9. B.-H. Yun, K. J. Kim, D. W. Joh, M. S. Chae, J. J. Lee, D.-W. Kim, S. Kang, D. Choi, S.-T. Hong, K. T. Lee, "Highly active and durable double-doped bismuth oxide-based oxygen electrodes for reversible solid oxide cells at reduced temperatures", J. Mater. Chem., A 7 20558-20566 (2019).

10. A. Chroneos, B. Yildiz, A. Tarancón, D. Parfitt, J. A. Kilner, "Oxygen diffusion in solid oxide fuel cell cathode and electrolyte materials: mechanistic insights from atomistic simulations”, Energy Environ. Sci., 4 27742789 (2011).

11. J.-H. Kim, "SOFC의 전해질 종류와 특성", Ceramist, 3 [5], 34-40 (2000).

12. N. Q. Minh, "Ceramic fuel cells", J. Am. Ceram. Soc., 76 [3], 563-588 (1993).

13. J. W. Fergus, "Electrolytes for solid oxide fuel cells”, J. Power Sources, 162 30-40 (2006).

14. D. A. Andersion, S. I. Simak, N. V. Skorodumova, I. A. Abrikosov, B. Johansson, "Optimization of ionic conductivity in doped ceria”, PNAS, 103[10], 3518-3521 (2006).

15. S. Omar, E. D. Wachsman, J. C. Nino, "Higher conductivity $\mathrm{Sm}^{3+}$ and $\mathrm{Nd}^{3+}$ co-doped ceriabased electrolyte materials", Solid State Ionics, 178 1890-1987 (2008).

16. A. Pesaran, A. Jaiswal, E. D. Wachsman, "Bilayer Electrolytes for Low Temperature and Intermediate Temperature Solid Oxide Fuel Cells - A Review”, Energy Storage and Conversion Materials, The Royal Society of Chemistry (2019).

17. S. boyapati, E. D. Wachsman, N. Jiang, "Effect of oxygen sublattice ordering on interstitial transport mechanism and conductivity activation energies in phasestabilized cubic bismuth oxides", Solid State Ionics, 140149 - 160 (2001).

18. H. A. Harwig, A.G.Gerards, "Electrical properties of the $\alpha, \beta, \gamma$, and $\delta$ phases of bismuth sesquioxide", J. Solid State Chem., 26 265-274 (1978).

19. M. J. Verkerk, K. Keizer, A. J. Burggraaf, "High oxygen ion conduction in sintered oxides of the $\mathrm{Bi}_{2} \mathrm{O}_{3}-\mathrm{Er}_{2} \mathrm{O}_{3}$ system", J. Appl. Electrochem., 10 81-90 (1980).

20. T. Takahashi, H. Iwahara, T. Arao, "High oxide ion conduction in sintered oxides of the system $\mathrm{Bi}_{2} \mathrm{O}_{3}-\mathrm{Y}_{2} \mathrm{O}_{3}$ ", J. Appl. Electrochem., 5 187-195 (1975).

21. M. J. Verkerk, A.J. Burggraaf, "High Oxygen Ion Conduction in Sintered Oxides of the $\mathrm{Bi}_{2} \mathrm{O}_{3}-\mathrm{Dy}_{2} \mathrm{O}_{3}$ System", J. Electrochem. Soc., 128 75-82 (1981).

22. P. - N. Huang, A. Petric, "Superior oxygen ion conductivity of lanthanum gallate doped with strontium and magnesium", J. Electrochem. Soc., 143 [5], 1644-1647 (1996).

23. H. Yahiro, Y. Baba, K. Eguchi. H. Arai, "High Temperature fuel cell with ceria-yttria solid electrolyte", J. Electrochem. Soc., $1352077-$ 2080 (1988).

24. F. M. B. Marques, L. M. Navarro, "Performance of double layer electrolyte cells Part II: GCO/ YSZ, a case study", Solid State Ionics, 100 29-38 (1997).

25. A. V. Virkar, "Theoretical Analysis of Solid Oxide Fuel Cells with Two-Layer, Composite Electrolytes: Electrolyte Stability”, J. Electrochem. 
Soc., 138 1481-1487 (1991).

26. T.-H. Kwon, T. Lee, H.-I. Yoo, "Partial electronic conductivity and electrolytic domain of bilayer electrolyte $\mathrm{Zr}_{0.84} \mathrm{Y}_{0.16} \mathrm{O}_{1.92} /$ $\mathrm{Ce}_{0.9} \mathrm{Gd}_{0.1} \mathrm{O}_{1.95}$ ", Solid State Ionics, 195 25-35 (2011).

27. D. -H. Myung, J. Hong, K. Yoon, B. -K. Kim, H.-W. Lee, J.-H. Lee, J.-W. Son, "The effect of an ultra-thin zirconia blocking layer on the performance of a $1-\mu \mathrm{m}$-thick gadolinia-doped ceria electrolyte solid-oxide fuel cell”, J. Power Sources 206 91-96 (2012).

28. Z. Gao, V. Y. Zenou, D. Kennouche, L. Marks, S. A. Barnett, "Solid oxide cells with zirconia/ ceria Bi-Layer electrolytes fabricated by reduced temperature firing", J. Mater. Chem. A, 3 9955-9964 (2015).

29. A. Infortuna, A. S. Harvey, L. J. Gauckler, "Microstructures of CGO and YSZ thin films by pulsed laser deposition", Adv. Funct. Mater., 18 127-135 (2008).

30. E.-O. Oh, C.-M. Whang, Y.-R. Lee, S. -Y. Park, D. H. Prasad, K. J. Yoon, J.-W. Son, J.-H. Lee, H. W. Lee, "Extremely thin bilayer electrolyte for solid oxide fuel cells (SOFCs) fabricated by chemical solution deposition (CSD)", Adv. Mater. 243373 -3377 (2012).

31. I. Jang, S. Kim, C. Kim, H. Lee, H. Yoon, T. Song, U. Paik, "Interface engineering of yttrium stabilized zirconia/gadolinium doped ceria bi-layer electrolyte solid oxide fuel cell for boosting electrochemical performance", $J$. Power Sources, 435 226776-226784 (2019).

32. C. Nicollet, J. Waxin, T. Dupeyron, A. Flura, J.-M. Heintz, J. P. Ouweltjes, P. Piccardo, A. Rougier, J.-C. Grenier, J.-M. Bassat, "Gadolinium doped ceria interlayers for Solid Oxide Fuel Cells cathodes: Enhanced reactivity with sintering aids ( $\mathrm{Li}, \mathrm{Cu}, \mathrm{Zn})$, and improved densification by infiltration", J. Power Sources, 372 157-165 (2017).

33. S. Lee, S. Lee, H.-J. Kim, S. M. Choi, H. An, M. Y. Park, J. Shin, J. H. Park, J. Ahn, D. Kim, H. -I. Ji, H. Kim, J.-W. Son, J.-H. Lee, B.-K. Kim, H.-W. Lee, J. Hong, D. Shin, K. J. Yoon, "Highly durable solid oxide fuel cells: suppressing chemical degradation via rational design of a diffusion-blocking layer", J. Mater. Chem. A, 6 15083-15094 (2018).

34. C. Kim, S. Kim, I. Jang, H. Yoon, T. Song, U. Paik, "Facile fabrication strategy of highly dense gadolinium-doped ceria/yttriastabilized zirconia bilayer electrolyte via cold isostatic pressing for low temperature solid oxide fuel cells", J. Power Sources, 415 112118 (2019).

35. K. T. Lee, D. W. Jung, M. A. Camaratta, H. S. Yoon, J. S. Ahn, E. D. Wachsman, " $\mathrm{Gd}_{0.1} \mathrm{Ce}_{0.9} \mathrm{O}_{1.95} / \mathrm{Er}_{0.4} \mathrm{Bi}_{1.6} \mathrm{O}_{3}$ bilayered electrolytes fabricated by a simple colloidal route using nano-sized $\mathrm{Er}_{0.4} \mathrm{Bi}_{1.6} \mathrm{O}_{3}$ powders for high performance low temperature solid oxide fuel cells", J. Power Sources, 205 122-128 (2012).

36. J. S. Ahn, D. Pergolesi, M. A. Camaratta, H. Yoon, B. W. Lee, K. T. Lee, D. W. Jung, E. Traversa, E. D. Wachsman, "Highperformance bilayered electrolyte intermediate temperature solid oxide fuel cells", Electrochem. Commun., 11 1504-1507 (2009).

37. D. W. Joh, J. H. Park, D. Kim, E. D. Wachsman, K. T. Lee, "Functionally Graded Bismuth Oxide/Zirconia Bilayer Electrolytes for High-Performance Intermediate-Temperature Solid Oxide Fuel Cells (IT-SOFCs)", ACS Appl. Mater. Interfaces, 9 8443-8449 (2017).

38. K. - N. Kim, J. Moon, J.-W. Son, J. Kim, H.-W. Lee, J.-H. Lee, B.-K. Kim, "Introduction of a Buffering Layer for the Interfacial Stability of LSGM-Based SOFCs", J. Korean Ceram. Soc., 42 637-644 (2005).

39. K. -N. Kim, J. Moon, H. Kim, J.-W. Son, J. Kim, H.-W. Lee, J.-H. Lee, B.-K. Kim, "Effect of Interfacial Reaction Layer on the Electrochemical Performance of LSGM-Based SOFCs", J. Korean Ceram. Soc., 42 665-671 (2005).

40. K. Huang, J.-H. Wan, J. B. Goodenough, "Increasing power density of LSGM-based solid oxide fuel cells using new anode materials", J. Electrochem. Soc., 148 [7], A788-A794 (2001).

41. K.-J. Kim, S.-W. Choi, M.-Y. Kim, M.-S. Lee, Y.-S. Kim, H.-S. Kim, "Fabrication characteristics of SOFC single cell with 
thin LSGM electrolyte via tape-casting and co-sintering", J. Ind. Eng. Chem., 42 69-74 (2016).

42. E. H. Song, T. J. Chung, H. -R. Kim, J.-W. Son, B. K. Kim, J.-H. Lee, H.-W. Lee, "Effect of the LDC Buffer Layer in LSGMbased Anode-supported SOFCs", J. Korean Ceram. Soc., 44 710-714 (2007).

43. J. Bi, B. Yi, Z. Wang, Y. Dong, H. Wu, Y. She,

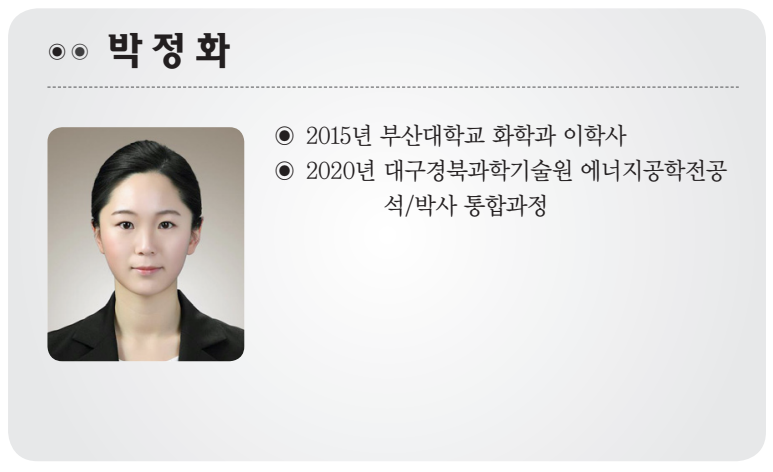

\section{․ 김 경 준}

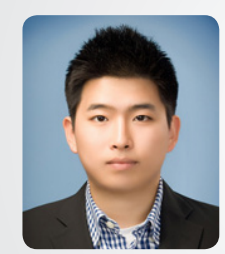

( 2013년 전남대학교 응용화학공학 공학사

- 2016년 전남대학교 신화학소재공학 공학석사

- 2020년 대구경북과학기술원 에너지공학전공 박사과정
M. Cheng, "A high-performance anodesupported SOFC with LDC-LSGM bilayer electrolytes”, Electrochem. Solid-State Lett., 7[5], A105-A107 (2004).

44. J. Bi, Y. Dong, M. Cheng, B. Yi, "Behavior of lanthanum-doped ceria and $\mathrm{Sr}-, \mathrm{Mg}-$ doped $\mathrm{LaGaO}_{3}$ electrolytes in an anode-supported solid oxide fuel cell with a $\mathrm{La}_{0.6} \mathrm{Sr}_{0.4} \mathrm{CoO}_{3}$ cathode", J. Power Sources, 161 34-39 (2006).

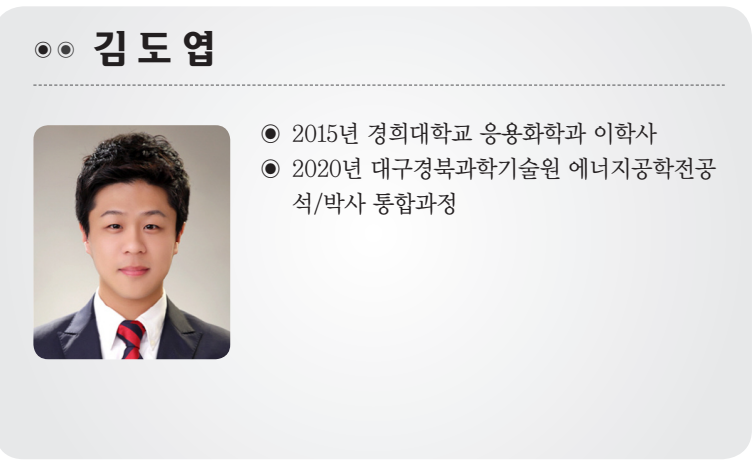

\section{으배 경택}

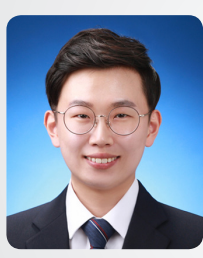

- 2017년 충남대학교 신소재공학과 공학사

- 2020년 대구경북과학기술원 에너지공학전공 석/박사 통합과정

\section{๑。이강 택}

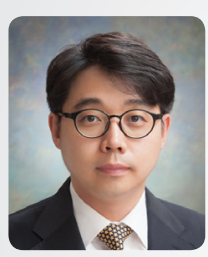

( 2002년 연세대학교 세라믹공학과 공학사

( 2005년 한국과학기술원 재료공학과 공학석사

○ 2005-2006년 LG전자 기술 연구소 연구원

๑ 2006-2010년 Univ. of Florida, Materials Science and Engineering 공학박사

๑ 2010-2013년 Univ. of Maryland Energy Research Center 박사 후 연구원

( 2013-2020년 대구경북과학기술원 에너지공학전공 조교수/부교수

0 2020년 한국과학기술원 기계공학과 부교수 